\title{
Research on the New Mode of Computer Education based on Project Driving Methodology and Teaching Practice
}

\author{
Wei $\mathrm{Ma}^{1}$ \\ ${ }^{1}$ Qinhuangdao Institute of Technology
}

\begin{abstract}
In this paper, we conduct research on the new mode of computer education based on project driving methodology and teaching practice. Computer education is an important part in college education, application of computer technology can effectively cultivate students' ability and quality of information. Collaborative project teaching method of the implementation of the method can make students accept knowledge by only listen into doing which will not only enhance the students' ability but help teachers obtain better feedback as well which is meaningful and necessary. The proposed methodology and education pattern is proven to be effective and feasible.
\end{abstract}

Keywords: Computer Education; Project Driving; Teaching Practice; Theoretical Analysis.

\section{INTRODUCTION}

With the continuous development of computer technology and popularization, it has been expanding the field of computer application. Thus the demand for computer technology to study will increase. Therefore, our country each colleges and universities have a computer professional. Computer education in colleges and universities in China provide a lot of computer professional and technical personnel, to promote the development of the computer industry in our country. But, rapid progress in the development of computer technology, computer education has brought challenge to colleges and universities. This request is engaged in the computer education of university teachers should keep up with the trend of the times, explore new teaching model. Network multimedia teaching is on the basis of learning resources to form a new type of teaching mode, its full play to the network has the characteristics of the learning content displayed to all students, is open and dynamic. Network media teaching is the most important in the design of the learning resources, the design of learning resources and teachers need to include cognitive learning counseling and course management of three parts. In this part of cognitive learning, need to include courses at the center of the teaching content, have relevant knowledge of the course content, such as background, review, etc. In addition, the expansion of the course content to be properly, effectively guide, develop test. This part teacher counseling, aims to provide information such as education policy and teaching skills to develop teachers' teaching quality, improve teachers' teaching level. Provide teachers with teaching experience exchange platform, improving teaching methods, improve the teaching effect. Curriculum management this part is to give full play to the role of the database to carry out effective teaching management [1].

Computer education is an important part in college education, application of computer technology can effectively cultivate students' ability and quality of information. In the context of current talent development demand, comprehensively improve the quality of the college students' ability is the basic standard of the university education, so to make full use of computer education, realize the talent cultivation of comprehensive ability. The computer education is the foundation of the 
college students' ability training. In the information age, computer technology is the basic means of survival and development, through the computer science and network to broaden the students' knowledge, knowledge is extended. In the process of broadening the horizons broaden the minds of students and cultivate the students' thinking ability which causes the student to have independent innovation consciousness. Computer education to organic combination innovative thinking and innovative ability and in a more direct and concrete forms to students, so that computer education to cultivate college students' ability to provide the basis. The major drawbacks of the current education pattern could be summarized as the follows. (1) University teachers' lack of scientific and advanced knowledge. Computer development in our country, after all, later than western countries, it also makes teachers engaged in the computer education in colleges and universities lack the necessary scientific and advanced knowledge systems. (2) Unable to follow the development trend of computer technology. As is known to all, change and development of computer technology is very fast, new technology and new products are introduced to computer education in colleges and universities has brought a lot of pressure. Coupled with the college computer teachers have no sense of time or to update their computer knowledge and technology, so still professor teaching backward hardware and software system of knowledge. Teachers can't follow the calculating technology development trend which makes the computer education and the social needs. (3) The computer education in colleges and universities lack sufficient cultural atmosphere. At present, the computer education in colleges and universities pay more attention to students' theoretical study, thus ignore the computer of the university students practical ability. (4) For computer skills training for students who are majoring in non-computer attention insufficient. In this way, the computer professional students can't learn more professional computer practical operation skills [2-3].

To deal with the mentioned challenges, in this paper, we conduct research on the new mode of computer education based on project driving methodology and teaching practice. Collaborative project teaching method of the implementation of the method can make students accept knowledge by only listen into doing and teachers are not easy to let the students according to the arrangement of the teachers and teaching to get a result, but under the guidance of teachers and students to seek ways to get the results. Finally get the results, and to display and self-assessment, stimulate students interest in learning in practice and exercise students' ability to work in the hand.

\section{Our Proposed Novel Methodology}

The Principles of the Computer Education. Should know the basic knowledge of computer and the computer knowledge effectively applied to field has become a basic requirement of computer education of contemporary university students. But now the present situation of computer education in colleges and universities is not optimistic. As a new era of talent, must master and apply the computer knowledge and technology. In the increasingly competitive modern society, to master the basic knowledge of computers is an essential skill. Computer education, however, in the training of the students' interests and skills also need to constantly reform and innovation, namely, optimize their teaching methods and means, so as to constantly adapt to social development and the work demand, for the society to create a more comprehensive high-quality, highly skilled personnel.

For the comprehensive reform of computer education, to establish the overall, the general situation of society, school propaganda the importance of computer education, and worked out the corresponding solution method and the corresponding measures. In view of the economically backward areas, especially in poor 
areas, should increase the computer teaching course, make the mountains children earlier to meet and understand contact computer. Many large computer course teaching, especially in higher vocational education, tend to be on a computer course, along with hundreds of people or more people the teacher can't understand the student's basic situation, the teaching content of feedback is also very slow. So the teacher can be in each class after decorate a task, let the students do after class, lets the student in the compulsory task digestive computer knowledge. According to the specific requirements for the students to learn computer, the students are divided into specialty, theory and application. Cultivation of computer talents should pay attention to students' individuality and targeted. Type of specialty students not only to let them master computer knowledge and the flexibility to use computer skillfully. Further excavate the potential ability of students, improve student ability to innovate. Of computer learning to care for other subjects of study, so should pay attention to cultivating their independent thinking ability and practical ability, so that the skilled application in work in the future. In the teaching, the application of computer to the teacher's teaching mode and teaching mode innovation, with the deepening of information level, just to apply multimedia in the classroom has been difficult to meet the actual needs of students and in this case, it is necessary to apply network teaching. Are the obvious advantages of network teaching itself, not only convenient and very large amount of information, now have got popularization.

The Project Driving Methodology. The implementation of the project teaching method which should be conditional, are implemented in different levels and different professional course, have different requirements and skills. Practice shows that high vocational computer professional courses, and some can carry out project teaching, some is very limited, do not blindly pursue fashion. To be able to carry out project teaching course, also need to implement project teaching of part teaching contents of choice. Before teaching, teachers should the teaching project feasibility study and fully understand the course content, students, and practical work. Project teaching method is the key to implementation and design and develops a project tasks, and keep the continuity of the project as soon as possible to keep systematic professional skills. Sometimes, to participate in the project learning of students from different majors and type of work, and even different professions, such as in addition to the computer professional, there are major mechanical and electrical major, purpose is to train practical reading as the ability to work with different professionals, department colleagues. Implement projects in the major of higher vocational computer teaching. Need to close connection with real life, especially in the future career life, cultivate the students' comprehensive qualities, and a variety of the ability. Project is project oriented in the teaching, the curriculum is decomposed into many small plates for teaching and on the one hand, to cultivate their theoretical level also can cultivate their knowledge to use. Project teaching method is based on the establishment of the theory of constructivism, the core of his major is the classroom the teacher and the students' classroom together, will be completed jointly proposed project by the teachers and students, among the process avoids the teacher closed the passive situation, has greatly aroused the students creative ability of thinking, more solid in the link of practice to master textbook knowledge.

The project teaching in the teaching steps could be summarized as the follows. (1) Scene setting. Creating and students learning content is the most close to the reality of the situation. (2) Demonstration operation. According to the laws of the knowledge migration, select the typical cases, demonstration and completing the process of a typical project. (3) To explore. Guide students to think, digest the case project key points on the solution of the problem. (4) 
Collaborative learning. Collaboration, according to the group together to complete the project, the teacher must for group activities for effective control, try to make every student to participate in the project process. (5) Learning evaluation. Students the final effect is measured through completion of the project, but the project teaching method pay more attention to the knowledge and skills of students learning process evaluation. In the figure one, we illustrate the principles of the project driving methodology.

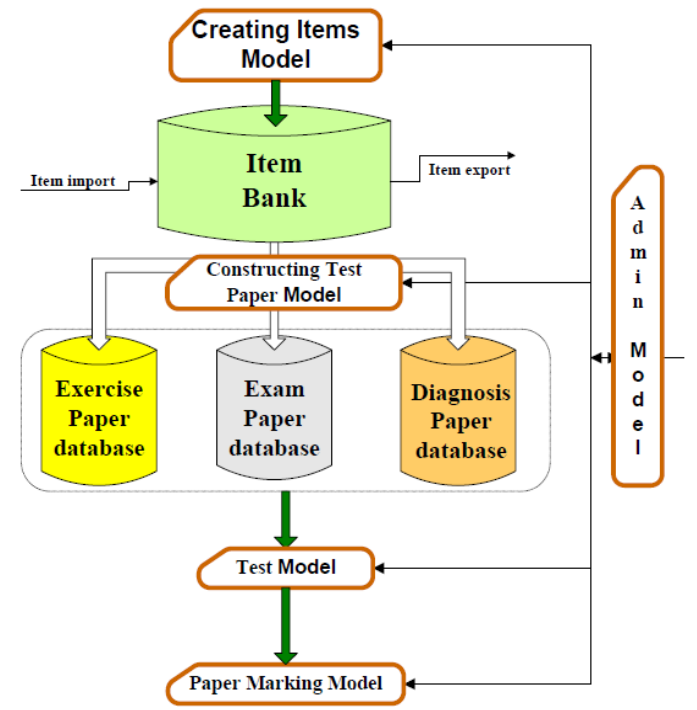

Figure 1. The Principles of the Project Driving Methodology

The Applications of the New Model. Task driven teaching method refers to a kind of based on constructivism teaching theory teaching method. It is both teachers and students to participate in an activity. The task analysis, discussed the answer to the problem in the cycle of put forward to solve problems. Not only to master the new knowledge. Also cultivate their ability to analysis, thinking and problem solving. In collaborative projects in teaching and learning process become a everyone involved in the creation of practice, pay attention to is not the final result, but the process to complete the project. Students in the process of project practice is aimed to understand and grasp the course requirements of knowledge and skills, difficulty and fun experience innovation, develop ideas and methods to analyze and solve problems. Select the appropriate project played a key role for the implementation of the project's success. In general, first of all, we want to consider the whole operation level of the students and their professional characteristics, avoid too professional and to attack the selected project, try to choose some modest project, because the project is too big, difficult to cause a decline in students' enthusiasm and confidence, on the other hand, the project is too simple, cannot achieve the purpose of the exercise the student beginning ability and thinking ability, must ensure that the content of the project within the scope of the students' comprehension.

The implementation of the project is driven by project teaching process. For all students to group division of labor, the team members accordingly complete the specified operation. Although public computer room for the management convenient and avoid the cross infection of the virus, generally prohibits students use mobile storage devices, but storing files convenience for students, has a remote question-answering system, every student can login system, file upload and download, the operation of the team members will each results generated files compressed package to upload. In the figure two, we demonstrate the designed pattern of computer education based on project driving. 


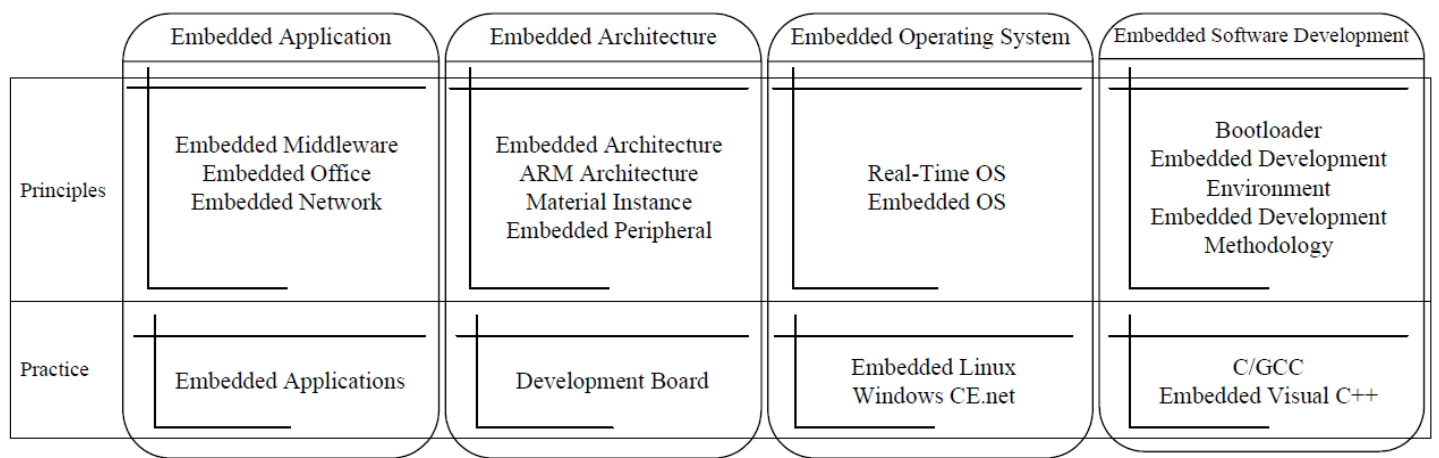

Figure 2. The Designed Pattern of Computer Education based on Project Driving

\section{Conclusion}

In this paper, we conduct research on the new mode of computer education based on project driving methodology and teaching practice. Through the teaching practice proved. In the task driving method in computer basic courses teaching, students' computer operation level has obviously improved. The teaching effect is greatly improves the task driving method teaching key is the teachers should determine the teaching objective. Grasp the teaching contents. It's more important is to choose the appropriate tasks. Stimulate students' learning interest and learning enthusiasm. The classroom task, acquire knowledge and skills task driving method of teaching can deepen students' understanding of classroom knowledge. In general conclusion, our proposed method has satisfactory result.

\section{References}

[1] Johnson A M, Reisslein J, Reisslein M. Representation sequencing in computerbased engineering education[J]. Computers \& Education, 2014, 72(1):249-261.

[2] Gulwani S. Example-based learning in computer-aided STEM education[J]. Communications of the Acm, 2014, 57(8):70-80.

[3] Education A T O C, v n Article Jun. Computer Science Education in French Secondary Schools: Historical and Didactical Perspectives[J]. Acm Transactions on Computing Education, 2014, 14. 